\title{
Heterosis for growth related traits in White Plymouth Rock and Single Comb White Leghorn reciprocal crosses reared under two crude protein regimens*
}

\author{
S. N. Nahashon², K. L. Ayorinde, P. Drummond, M. Dawes \\ and E. J. Smith \\ Animal Genetics Laboratory, \\ 103 Milbank Hall. Tuskegee University \\ Tuskegee, AL 36088, USA
}

(Received 23 March 1998; accepted 19 November 1998)

\begin{abstract}
Studies of dietary effects on heterosis for body weight gain (BWG) and feed conversion ratio (FCR) are few. In the present work, heterosis, heterosis due to sex chromosome, and maternal and line effects for BWG and FCR were compared in reciprocal crosses of White Plymouth Rock (WPR) and Single Comb White Leghorn (SCWL). These birds were reared on either 18 or $20 \%$ crude protein (CP) diets from hatch to 8 weeks. The WPR birds exhibited larger body weights and consumed more feed than the SCWL birds. Also WPR birds on $20 \% \mathrm{CP}$ diet were larger than those on $18 \%$ CP diet. Although FCR of SCWL birds on $18 \%$ CP diet was lower than those on $20 \%$ CP diet at 1 and 3-6 weeks, FCR was lower in WPR than SCWL birds. Heterosis was higher at 18\% CP diets and the average maternal and line effects for BWG were higher $(\mathrm{P}<0.05)$ for WPR than SCWL and at 18 than $20 \% \mathrm{CP}$ diets. However, maternal effects for FCR of WPR progeny were higher at 20 than $18 \%$ CP dicts. Average line effects were also higher for WPR than SCWL males and significant at $20 \% \mathrm{CP}$ diets for both lines. Heterosis due to sex chromosome was significant $(\mathrm{P}<0.05)$ and positive for BWG but negative for FCR. This study indicates that SCWL males and WPR females exhibited higher combining ability at 18 than $20 \% \mathrm{CP}$ diets. The significant heterosis for $\mathrm{BWG}$ and $\mathrm{FCR}$ due to sex chromosomes and maternal effects suggest that these two traits are also affected by genes on the sex chromosome.
\end{abstract}

KEY WORDS: heterosis, crude protein, chickens, performance

* Contribution Number 298 of the George Washington Carver Agricultural Experiment Station, USA 


\section{INTRODUCTION}

Heterosis, the average performance of progeny relative to their genetically distinct parents, has been extensively used in the poultry industry to measure performance and maximize production. There is, however, no other reliable method to predict the level of heterosis that will occur from the mating of individuals from two populations unless the traits are measured in the offspring. Likewise, there is no accurate method of estimating the optimum nutrient requirements of the offspring from these crosses since heterosis will vary with populations included in the cross and environmental changes, including dietary nutrient composition (Barlow, 1981).

Although varied and inconclusive, changes in heterosis have also been found with respect to nutritional treatment (Hull et al., 1963; Emsley et al., 1980). Thus, the relative feed conversion efficiency of individual birds or different strains of birds with different specific nutrient requirements may be affected by the nutrient composition of the diet used. According to Noble et al. (1993) and Pincard et al. (1993), fast-growing chickens are more sensitive to protein and amino acid concentration in diets. Similar observations involving dietary protein concentration were reported by Hruby et al. (1995) and Siegel et al. (1997). Thus, estimation of heterosis may also be influenced by dietary protein concentration.

This study was, therefore, designed to evaluate the effect of dietary crude protein level on heterosis and reciprocal effects for feed efficiency and body weight gain in crosses involving White Plymouth Rock and Single Comb White Leghorn. These two traits are commonly used in determining performance of both meat and egg-type birds. Further, these traits with an estimated correlation of +0.52 have been of both biological and economic significance towards genetic improvement through selection of faster growing and high producing birds (Chambers et al., 1984; Leenstra et al., 1986).

\section{MATERIAL AND METHODS}

\section{Crosses}

In two replicates, 100 each of Single Comb White Leghorn (SCWL) and White Plymouth Rock (WPR) progeny of either sex were reared separately on 18 and $20 \% \mathrm{CP}$ diets (Table 1) from hatch to 8 weeks of age (WOA) after which they were fed commercial diets (NRC, 1994) through the growth and breeding periods. At 18 weeks of age, 10 cocks and 40 females were sampled from each line and dietary treatment and randomly placed in individual laying cages throughout the breeding period. The crosses were produced by pedigree mating ( 1 male: 4 fe- 
Composition of experimental diets, \%

\begin{tabular}{lcc}
\hline Ingredients & $\mathrm{CP}, \%$ & 18 \\
\hline Maize, yellow $(8 \% \mathrm{CP})$ & 68.86 & 63.76 \\
Soyabean meal $(48 \% \mathrm{CP})$ & 25.60 & 30.20 \\
Lucerne meal $(17 \% \mathrm{CP})$ & 1.00 & 1.00 \\
Poultry blended fat & 0.46 & 0.96 \\
Dicalcium phosphate $(18.5 \% \mathrm{P}, 24 \% \mathrm{Ca})$ & 2.10 & 2.10 \\
Limestone flour $(37 \% \mathrm{Ca})$ & 0.93 & 0.94 \\
DL-Methionine & 0.10 & 0.09 \\
Salt & 0.37 & 0.37 \\
Vitamin premix & 0.25 & 0.25 \\
Trace mineral premix ${ }^{2}$ & 0.25 & 0.25 \\
Coban 60 & 0.08 & 0.08 \\
Calculated levels & & \\
CP & 18 & 20 \\
Kcal ME/kg & 3.000 & 3.000 \\
calcium & 0.99 & 0.98 \\
total P & 0.67 & 0.67 \\
availailable P & 0.40 & 0.40 \\
Met & 0.30 & 0.30 \\
Met + Cyst & 0.56 & 0.56 \\
\hline
\end{tabular}

' - provided per kg of diet: retinyl acetate, $3337 \mathrm{IU}$; cholecalciferol, $1000 \mathrm{ICU}$; dl-tocopheryl acetate, $3.6 \mathrm{IU}$; menadione sodium bisulfitc complex, $2.8 \mathrm{mg}$; vitamin $\mathrm{B}_{12}, 6.1 \mathrm{mg}$; riboflavin, $2.5 \mathrm{mg}$; pantothenic acid, $5.9 \mathrm{mg}$; niacin, $16.4 \mathrm{mg}$; choline, $227 \mathrm{mg}$; folic acid, $230 \mu \mathrm{g}$; cthoxyquin, $56.7 \mathrm{mg}$ ${ }^{2}$ - provided per kg of diet: $\mathrm{Mn}, 65 ; \mathrm{J}, 1 ; \mathrm{Fe}, 54.8 ; \mathrm{Cu}, 6 ; \mathrm{Zn}, 55 ; \mathrm{Se}, 3$

males) via artificial insemination. Both purebred and crossbred progeny were obtained in a single hatch from a 14-day egg collection. To ensure hatching ability, the eggs were stored in a cold room $\left(13-15^{\circ} \mathrm{C}\right.$ and $75-80 \%$ relative humidity) until incubated.

\section{Design}

In three replicates, a total of $1,178 \mathrm{~F} 1$ reciprocal crosses of SCWL and WPR parental populations were randomly assigned to isocaloric $(3,000 \mathrm{Kcal} \mathrm{ME} / \mathrm{kg})$ diets containing 18 and $20 \% \mathrm{CP}$ (Table 1) from hatch to $8 \mathrm{WOA}$. Chickens of each cross and the purelines were weighed at hatch and placed on the two dietary treatments for the eight weeks and raised using standard brooding techniques (North and Bell, 1990). The two diets were fed ad libitum in mash form. Body weight $(\mathrm{BW})$ and feed consumption (FC), from which feed conversion ratios (FCR) were calculated, were measured weekly. 
Statistical analysis

The statistical model used to represent the mean of a specific parental line or cross within sex and dietary crude protein levels adopted from Eisen et al. (1984) and modified by Barbato et al. (1991) was:

where:

$$
\mathrm{Y}_{\mathrm{ij}}=\hat{\mathrm{y}}_{\mathrm{a}}+\left(\mathrm{l}_{\mathrm{i}}+\mathrm{l}_{\mathrm{j}}\right) / 2+\mathrm{m}_{\mathrm{j}}+* \mathrm{~h}_{\mathrm{ij}}
$$

$\mathrm{Y}_{\mathrm{ij}}=$ the mean performance of sire line $\mathrm{i}$ crossed with dam line $\mathrm{j}(*=0$ for parental line progeny and $*=1$ for crossbred progeny),

$\hat{y}_{\mathrm{a}}=$ mean of the parental lines,

$\mathrm{m}_{\mathrm{j}}=\hat{\mathrm{y}}_{\mathrm{j}}+\hat{\mathrm{y}}_{\mathrm{j} .}$,

$\mathrm{L}_{\mathrm{i}}=\hat{\mathrm{y}}_{\mathrm{ii}}-\hat{\mathrm{y}}_{\mathrm{a}}-\mathrm{m}_{\mathrm{i}}$,

$\mathrm{h}_{\mathrm{ij}_{2}}=1\left(\hat{\mathrm{y}}_{\mathrm{ij}}+\hat{\mathrm{y}}_{\mathrm{ji}}-\hat{\mathrm{y}}_{\mathrm{ii}}-\hat{\mathrm{y}}_{\mathrm{jj}}\right)$

Specific reciprocal effects (independent of $m_{j}$ ) were assumed to be zero in this model.

According to Carbonell et al. (1984), heterosis in males $\left(\mathrm{h}_{\mathrm{ij}}^{\mathrm{p}}\right)$ and females $\left(\mathrm{h}_{\mathrm{ij}}^{\mathrm{f}}\right)$ has different expectations such that:

where:

1. $h^{\mathrm{p}}{ }_{\mathrm{ij}}=\mathrm{h}^{\mathrm{a} i j}+\mathrm{h}^{\mathrm{s}} \mathrm{ij}+\mathrm{aa^{ \textrm {h } }}{ }_{\mathrm{ij}}$

2. $h^{\mathrm{f}} \mathrm{ij}^{\mathrm{ij}}=\mathrm{h}_{\mathrm{ij}}^{\mathrm{a}}+\mathrm{aa}^{\mathrm{h}} \mathrm{ij}$

$h^{\mathrm{a}}{ }_{\mathrm{ij}}=$ specific heterosis of the autosomes

$h^{s}{ }_{i j}=$ specific heterosis of the sex chromosomes (only in males) and

$\mathrm{aa}^{\mathrm{h}}{ }_{\mathrm{ij}}=$ specific additive-by-additive heterosis.

Solving for $h^{\mathrm{s}}$ in the simultaneous equations 1 and 2 :

$h_{i j}^{s}=h_{i j}^{p}-h_{i j}^{i}$; this equation was used to estimate heterotic effects due to heterozygosity of the sex chromosomes, which can only occur in the homogametic sex (Carbonell et al., 1984).

Significance of heterosis, line and maternal effects was evaluated by the Student's $t$-test with $\mathrm{n}$ - $\mathrm{r}$ degrees of freedom, with $\mathrm{n}$ being the total number of observations $(1,178)$ and $r$ the number of groups $(8)$. The analyses were performed using the General Linear Model (GLM) procedure of SAS ${ }^{\text {p: }}$ (SAS Institute, 1990).

\section{RESULTS AND DISCUSSION}

Body weight gain, feed consumption, and feed conversion ratio

The body weight gains (BWG), feed consumption (FCR) and feed conversion ratio (FCR) are presented in Table 2 . Since there were no significant diet $\mathrm{x}$ sex 
TABLE 2

Average weekly feed consumption and body weight gain (g/bird/week) and feed conversion ratio (g feed/g BWG) of White Plymouth Rock (WPR) and Single Comb White Leghorn (SCWL) birds fed 18 and 20\% crude protein diets

\begin{tabular}{|c|c|c|c|c|c|c|c|c|c|c|c|c|c|c|c|c|}
\hline \multirow{2}{*}{$\begin{array}{l}\text { AGE, weeks } \\
\text { CP, } \%\end{array}$} & \multicolumn{2}{|l|}{1} & \multicolumn{2}{|c|}{2} & \multicolumn{2}{|c|}{3} & \multicolumn{2}{|c|}{4} & \multicolumn{2}{|c|}{5} & \multicolumn{2}{|c|}{6} & \multicolumn{2}{|c|}{7} & \multicolumn{2}{|l|}{8} \\
\hline & 18 & 20 & 18 & 20 & 18 & 20 & 18 & 20 & 18 & 20 & 18 & 20 & 18 & 20 & 18 & 20 \\
\hline \multicolumn{17}{|l|}{ Fecd consumption } \\
\hline WPR & $69^{b}$ & $65^{b}$ & $128^{a}$ & 133 & $169^{a y}$ & $187^{\times}$ & $253^{\text {ay }}$ & $266^{a x}$ & $311^{\text {ay }}$ & $337^{3 x}$ & $378^{\mathrm{a}}$ & $374^{a}$ & $438^{y}$ & $459^{a x}$ & $406^{a x}$ & $333^{\text {by }}$ \\
\hline SCWL & $79^{\cdots x}$ & $69^{a y}$ & $120^{\text {by }}$ & $127^{x}$ & $158^{\text {by }}$ & $188^{x}$ & $240^{\text {by }}$ & $251^{\mathrm{bx}}$ & $282^{\text {by }}$ & $316^{\mathrm{bx}}$ & $314^{b v}$ & $355^{\mathrm{bx}}$ & $436^{y}$ & $452^{\mathrm{bx}}$ & $333^{\text {by }}$ & $343^{a x}$ \\
\hline Pooled SEM ${ }^{1}$ & 0.8 & 0.6 & 0.8 & 0.4 & 0.2 & 1.1 & 2.8 & 1.8 & 2.2 & 1.2 & 4.0 & 2.0 & 1.0 & 0.7 & 2.2 & 1.8 \\
\hline \multicolumn{17}{|l|}{ Body weight gain } \\
\hline WPR & 37 & 36 & $64^{\mathrm{a}}$ & 61 & $79^{a}$ & $83^{a}$ & 98 & 93 & $119^{3}$ & $119^{\circ}$ & $129^{a}$ & $123^{a}$ & $131^{y}$ & $140^{a x}$ & $147^{a x}$ & $138^{\mathrm{ay}}$ \\
\hline SCWL & 35 & 35 & $53^{b}$ & 57 & $65^{b}$ & $68^{b}$ & 92 & 89 & $95^{\mathrm{h}}$ & $96^{b}$ & $89^{b}$ & $93^{b}$ & 126 & $127^{\mathrm{b}}$ & $99^{b}$ & $99^{b}$ \\
\hline Pooled SEM ${ }^{1}$ & 1.1 & 1.2 & 1.4 & 1.5 & 1.8 & 2.1 & 2.4 & 2.4 & 2.8 & 3.0 & 3.0 & 3.2 & 3.5 & 3.0 & 3.9 & 3.6 \\
\hline \multicolumn{17}{|l|}{ Feed conversion } \\
\hline WPR & $1.95^{\mathrm{b}}$ & $1.87^{b}$ & $2.05^{\mathrm{b}}$ & $2.15^{\mathrm{b}}$ & 2.25 & $2.36^{\mathrm{b}}$ & 2.75 & 2.99 & $2.79^{\mathrm{b}}$ & $2.95^{\mathrm{b}}$ & $3.03^{b}$ & $3.10^{\mathrm{b}}$ & $3.49^{x}$ & $3.34^{y}$ & $2.91^{\text {by }}$ & $3.24^{b x}$ \\
\hline SCWL & $2.33^{\mathrm{ax}}$ & $2.05^{\mathrm{wy}}$ & $2.31^{\mathrm{a}}$ & $2.24^{\mathrm{a}}$ & $2.53^{y}$ & $2.86^{\mathrm{ax}}$ & $2.67^{y}$ & $2.87^{x}$ & $3.03^{\mathrm{ay}}$ & $3.36^{\mathrm{ax}}$ & $3.55^{\mathrm{ay}}$ & $3.87^{a x}$ & 3.51 & 3.60 & $3.52^{\mathrm{a}}$ & $3.59^{a}$ \\
\hline $\mathrm{SEM}^{\mathrm{j}}$ & 0.04 & 0.05 & 0.05 & 0.04 & 0.06 & 0.08 & 0.07 & 0.06 & 0.07 & 0.09 & 0.08 & 0.07 & 0.09 & 0.12 & 0.09 & 0.11 \\
\hline
\end{tabular}

$\mathrm{a}, \mathrm{b}-$ means within columns with no common superscript differ significantly $(\mathrm{P} \leq 0.05)$

$\mathrm{x}, \mathrm{y}$ - means within rows of two consecutive columns representing 18 and $20 \% \mathrm{CP}$ with no common superscript differ significantly (P $\leq 0.05$ )

1 - pooled means for males and females 
interactions on BWG, FC and FCR, data for both sexes were pooled prior to comparison of means. As expected, WPR birds exhibited larger body weights and consumed more feed than the SCWL birds. The higher feed consumption of WPR birds is justified by their rapid growth rate and supported by reports of Pesti (1982) and Leeson et al. (1993) that birds adjust feed intake to meet their energy requirement for both growth and maintenance. Since these birds were fed isocaloric diets $(3,000 \mathrm{Kcal} \mathrm{ME} / \mathrm{kg})$, its expected that the lean birds (SCWL) show less response to dietary fat than WPR birds (Karen-Zvi et al., 1990). It is also probably true that faster growing birds deposit more fat than their slow-growing counterparts (Pesternak and Slalev, 1983). Although differences in BWG of birds on 18 and $20 \%$ $\mathrm{CP}$ diets were not significant for most of the study period, birds on $20 \% \mathrm{CP}$ diet consumed more feed than those on $18 \% \mathrm{CP}$ diet. These observations were consistent with previous reports (Sengar, 1987; Leeson and Summers, 1989; Skinner et al., 1992) that birds on diets with relatively higher levels of CP consume more feed. The FCR was lower for SCWL birds on $18 \%$ than $20 \%$ CP diets at 1 and 3-6 weeks and also lower in WPR than SCWL birds. These results are consistent with those reviewed by Pym (1990), where birds with higher growth rate utilised nutrients more efficiently. Similarly, observations by Sabri et al. (1991) of genetic differences in feed efficiency were reported to be due to differences in energy requirements for growth for the genetic lines evaluated. Consistent with this rationale of the biological relationship between FCR and BWG were high phenotypic and genetic correlation estimates reported by Chambers et al. (1984).

\section{Heterosis}

The mean heterotic effect, percent heterosis and heterosis for sex-linked effects for body weight gain are presented in Table 3 . Significant and negative average heterosis, ranging from -19 to 20 and -48 to -9 in male and female progeny, respectively, was observed for BWG except at 2 WOA. Although with a great deal of variation, heterosis was highly negative at 1 WOA and increased with age of birds. These observations were, in part, consistent with previous reports of Verma and Chaudhary (1980). Fairfull (1990) also reported a great deal of variation in heterosis between crosses of pairs of strains and this heterosis depended on the nature and degree of the genetic difference between strains. Even though the average heterosis for females was also significant throughout the studied period, males exhibited higher heterosis than females in most part of the study except at 4 and 6 WOA. The higher heterosis for male than female progeny suggest that there was positive heterosis for body weight gain due to the sex chromosome among the male progeny. Average heterosis for sex chromosome was also significant throughout the study period. In most part, the average heterosis for males and heterosis for sex chromosome was 186 and $14 \%$ higher at 18 than $20 \% \mathrm{CP}$ diets, respectively. 
TABLE 3

Heterosis $\left(h_{i j}\right)$, percent heterosis $\left(\% h_{i j}\right)$ and heterosis for sex linked effects $\left(h_{i}^{\vee}\right)$ for body weight gain of White Plymouth Rock (WPR) and Single Comb White Leghorn (SCWL) reciprocal crosses on 18 and $20 \%$ crude protein diets

\begin{tabular}{|c|c|c|c|c|c|c|c|c|c|c|c|c|c|c|c|c|c|c|}
\hline \multirow[b]{2}{*}{ Sex } & \multirow[b]{2}{*}{ Effect } & \multirow{2}{*}{$\begin{array}{c}\text { Age, weeks } \\
\text { CP, } \%\end{array}$} & \multicolumn{2}{|c|}{1} & \multicolumn{2}{|c|}{2} & \multicolumn{2}{|c|}{3} & \multicolumn{2}{|c|}{4} & \multicolumn{2}{|c|}{5} & \multicolumn{2}{|c|}{6} & \multicolumn{2}{|c|}{7} & \multicolumn{2}{|c|}{8} \\
\hline & & & 18 & 20 & 18 & 20 & 18 & 20 & 18 & 20 & 18 & 20 & 18 & 20 & 18 & 20 & 18 & 20 \\
\hline \multirow[t]{4}{*}{ Male } & $h_{i j}$ & & -13 & -13 & NS & NS & NS & NS & -8 & NS & NS & -9 & 20 & 16 & -13 & -19 & 8 & NS \\
\hline & $\% \mathrm{~h}_{\mathrm{ij}}$ & & -32 & -36 & NS & NS & NS & -8 & -8 & NS & NS & -9 & 18 & 15 & -10 & -14 & NS & NS \\
\hline & $\mathbf{h}_{i}^{\mathrm{s}^{1}}$ & & NS & NS & 8 & 9 & 11 & 10 & 15 & 15 & 20 & 20 & 27 & 22 & 29 & 29 & 32 & 16 \\
\hline & $\% \mathrm{~h}^{\mathrm{s}}$ & & 5.5 & 10 & 6 & 15 & 12 & 13 & NS & 17 & 8 & 18 & 21 & 21 & NS & 22 & 16 & 24 \\
\hline \multirow[t]{3}{*}{ Female } & $h_{i}$ & & NS & -13 & -9 & -10 & NS & NS & -13 & -15 & -24 & -29 & NS & NS & -42 & -48 & -24 & -35 \\
\hline & $\% \mathbf{h}_{i 1}$ & & -23 & -46 & -8 & -17 & NS & 8 & -12 & -17 & -11 & -27 & NS & NS & -17 & -36 & -10 & -29 \\
\hline & \multicolumn{18}{|c|}{$\mathrm{SE}^{\prime}=1.2-8.1$} \\
\hline
\end{tabular}

* - significant heterosis $(\mathrm{P}<0.05)$

1 - standard error of mean

NS - non significant

TABLE 4

Heterosis $\left(\mathrm{h}_{\mathrm{ij}}\right)$, percent hetcrosis $\left(\% \mathrm{~h}_{\mathrm{ii}}\right)$ and heterosis for sex linked effects $\left(\mathrm{h}_{\mathrm{i}}^{\mathrm{s}}\right)$ for feed conversion ratios of White Plymouth Rock (WPR) and Single Comb White Leghorn (SCWL) reciprocal crosses on 18 and $20 \%$ crude protein diets

\begin{tabular}{|c|c|c|c|c|c|c|c|c|c|c|c|c|c|c|c|c|c|c|}
\hline \multirow[b]{2}{*}{ Sex } & \multirow[b]{2}{*}{ Effect } & \multirow{2}{*}{$\begin{array}{c}\text { Age, weeks } \\
\text { CP, } \%\end{array}$} & \multicolumn{2}{|c|}{1} & \multicolumn{2}{|c|}{2} & \multicolumn{2}{|c|}{3} & \multicolumn{2}{|c|}{4} & \multicolumn{2}{|c|}{5} & \multicolumn{2}{|c|}{6} & \multicolumn{2}{|c|}{7} & \multicolumn{2}{|c|}{8} \\
\hline & & & 18 & 20 & 18 & 20 & 18 & 20 & 18 & 20 & 18 & 20 & 18 & 20 & 18 & 20 & 18 & 20 \\
\hline \multirow[t]{4}{*}{ Male } & $h_{i j}$ & & 0.34 & 0.21 & NS & NS & NS & NS & NS & -0.37 & -0.27 & -0.47 & -0.46 & -0.7 & NS & -0.26 & NS & 0.25 \\
\hline & $\% \mathrm{~h}_{\mathrm{ij}}$ & & 16 & 11 & NS & NS & NS & NS & NS & -13 & -9.4 & -15 & -14 & -20 & NS & NS & NS & 7 \\
\hline & $h_{i}^{s^{\prime \prime}}$ & & -0.52 & -0.31 & -0.5 & -0.43 & -0.37 & -0.58 & -0.51 & -0.65 & -0.54 & -0.75 & -0.58 & -0.91 & -1 & -1 & -1.4 & \\
\hline & $\% h_{i}^{\prime}$ & & -4.2 & -20 & -9 & -21 & -7 & -14 & -11 & -18 & -16 & -17 & -19 & -17 & -16 & -30 & -14 & -40 \\
\hline \multirow[t]{3}{*}{ Female } & $\mathrm{h}_{\mathrm{ij}}$ & & 0.81 & 0.61 & 0.22 & 0.27 & 0.51 & 0.23 & 0.56 & NS & 0.37 & NS & 0.29 & NS & 0.71 & 0.79 & 1.2 & 1.6 \\
\hline & $\% \mathrm{~h}_{\mathrm{ij}}$ & & -20 & 31 & NS & 12 & 11 & 8.8 & 10 & NS & 6.4 & NS & NS & NS & 10 & 22 & 19 & 47 \\
\hline & \multicolumn{18}{|c|}{$\mathrm{SE}^{1}=0.04-0.3$} \\
\hline
\end{tabular}

1 - standard error of mean

NS - non significant 
Although changes in heterosis have been reported with respect to nutritional treatment (Hull et al., 1963; Emsley et al., 1980), differences for 8 week average heterosis for females on either 18 or $20 \% \mathrm{CP}$ diets were not significant.

Average heterosis for FCR of male and female crossbred progeny are presented in Table 4. The high variation in FCR may be due to residual feed consumption (Byerly et al., 1980) which has a genetic basis (Schulman et al., 1994). The average heterosis for FCR of male progeny was negative and significant in most part of the study except at 2 and 4 WOA, whereas the average heterosis for females was positive and significant throughout the study period. The heterosis values for males and females on 18 and $20 \% \mathrm{CP}$ diets ranged from -0.46 to 0.34 and 0.22 to 1.2 , and -0.47 to 0.25 and 0.23 to 1.6 , respectively. The lower average heterosis for males is due to the negative and significant heterosis due to the sex chromosome in males. On averaging means for the 8 weeks study period, heterosis was 260 and $48 \%$ higher at 18 than $20 \% \mathrm{CP}$ diets for males and females, respectively. Percent heterosis for sex chromosome was also $4 \%$ higher at 18 than $20 \% \mathrm{CP}$ diets.

\section{Maternal and line effects}

With the exception of females on $18 \%$ CP diet, maternal effects on body weight gain (Table 5) were positive and significant for WPR males and females at 6 and 8 WOA, whereas for the most part birds on $18 \% \mathrm{CP}$ diet exhibited higher maternal effects ( -19 to 24 and -18 to 11 , respectively) than those on $20 \% \mathrm{CP}$ diet ( -27 to 18 and -19 to 11 , respectively). The observed differences in patterns of heterosis due to maternal and line effects with age and CP levels is suggestive of the existence of line $x$ diet interactions. Average line effects were positive, significant although greater for WPR than SCWL males. Average line effect for both WPR and SCWL females was in most part negative but significantly higher in WPR than SCWL progeny. Average line effects for WPR males and females were also 40 and $176 \%$ higher, respectively, at 20 than $18 \%$ CP diets.

Average maternal effects on feed conversion ratio were not significant for the most part of the study for progeny of both sexes (Table 6). Maternal effects of WPR males and females ranged from -0.85 to 0.61 and -0.61 to 0.81 , respectively. Average maternal effects for WPR males and females was 116 and $271 \%$ higher at 20 than $18 \%$ CP diets.

Average line effects for WPR males were higher than SCWL and significant at $20 \% \mathrm{CP}$ diets for both lines (Tables 5 and 6 ). The reverse trend was observed in females and especially from 6 to 8 WOA where line effects were significant for both WPR and SCWL progeny. However, SCWL progeny exhibited higher average line effects than WPR during this study period. Line effect in males and fe- 
TABLE 5

Maternal $\left(\mathrm{M}_{\mathrm{ij}}\right)$ and line $\left(\mathrm{L}_{11}\right)$ effects for body weight gain of White Plymouth Rock (WPR) and Single Comb White Leghorn (SCWL) reciprocal crosses on 18 and $20 \%$ crude protein diets

\begin{tabular}{|c|c|c|c|c|c|c|c|c|c|c|c|c|c|c|c|c|c|c|}
\hline \multirow[b]{2}{*}{ Sex } & \multirow[b]{2}{*}{ Effect } & Agc, wecks & \multicolumn{2}{|c|}{1} & \multicolumn{2}{|c|}{2} & \multicolumn{2}{|c|}{3} & \multicolumn{2}{|c|}{4} & \multicolumn{2}{|c|}{5} & \multicolumn{2}{|c|}{6} & \multicolumn{2}{|c|}{7} & \multicolumn{2}{|c|}{8} \\
\hline & & $\mathrm{CP}, \%$ & 18 & 20 & 18 & 20 & 18 & 20 & 18 & 20 & 18 & 20 & 18 & 20 & 18 & 20 & 18 & 20 \\
\hline \multirow[t]{3}{*}{ Male } & \multirow{3}{*}{\multicolumn{2}{|c|}{$\begin{array}{l}\left(M_{i j}\right) \text { WPR } \\
\left(L_{i j}\right) W P R \\
\text { SCWL }\end{array}$}} & NS & NS & NS & NS & 9 & NS & NS & NS & NS & NS & 24 & 15 & -19 & -27 & 13 & 18 \\
\hline & & & NS & NS & NS & NS & 11 & 17 & 15 & 21 & 37 & 39 & 10 & 19 & 18 & 30 & 35 & 35 \\
\hline & & & NS & NS & NS & 7 & NS & NS & NS & NS & NS & NS & 18 & 11 & NS & -20 & NS & NS \\
\hline \multirow[t]{3}{*}{ Female } & \multirow{3}{*}{\multicolumn{2}{|c|}{$\begin{array}{l}\left(\mathrm{M}_{\mathrm{ij}} \mathrm{WPR}\right. \\
\text { SCWL }\end{array}$}} & NS & NS & NS & NS & NS & NS & -12 & NS & NS & NS & NS & 12 & 24 & 29 & NS & -26 \\
\hline & & & NS & NS & NS & NS & NS & -11 & NS & -11 & -31 & -41 & -23 & -18 & -36 & -38 & NS & -15 \\
\hline & & & \multicolumn{16}{|c|}{$\mathrm{SE}^{\prime}\left(\mathrm{M}_{\mathrm{ij}}\right)=1.3-5.9 \mathrm{SE}^{\prime}\left(\mathrm{L}_{\mathrm{ij}}\right)=1.2-6.0$} \\
\hline
\end{tabular}

1 - standard crror of mean

$\mathrm{NS}$ - non significant

TABLE 6

Maternal $\left(\mathrm{M}_{\mathrm{ij}}\right)$ and line $\left(\mathrm{L}_{\mathrm{ii}}\right)$ effects for feed conversion ratios of White Plymouth Rock (WPR) and Single Comb White Leghorn (SCWL) reciprocal crosses on 18 and $20 \%$ crude protein diets

\begin{tabular}{|c|c|c|c|c|c|c|c|c|c|c|c|c|c|c|c|c|c|c|}
\hline \multirow[b]{2}{*}{ Sex } & \multirow[b]{2}{*}{ Effect } & \multirow{2}{*}{$\begin{array}{l}\text { Age, weeks } \\
\text { CP, } \%\end{array}$} & \multicolumn{2}{|c|}{1} & \multicolumn{2}{|c|}{2} & \multicolumn{2}{|c|}{3} & \multicolumn{2}{|c|}{4} & \multicolumn{2}{|c|}{5} & \multicolumn{2}{|c|}{6} & \multicolumn{2}{|c|}{7} & \multicolumn{2}{|c|}{8} \\
\hline & & & 18 & 20 & 18 & 20 & 18 & 20 & 18 & 20 & 18 & 20 & 18 & 20 & 18 & 20 & 18 & 20 \\
\hline \multirow[t]{3}{*}{ Male } & \multirow{3}{*}{\multicolumn{2}{|c|}{$\begin{array}{c}\left(M_{i j}\right) W P R \\
\left(L_{i j}\right) W P R \\
\text { SCWL }\end{array}$}} & -0.85 & NS & NS & NS & NS & NS & NS & NS & NS & NS & -0.68 & NS & NS & 0.61 & NS & -0.61 \\
\hline & & & NS & NS & NS & NS & NS & $-0.53^{-}$ & NS & -0.45 & NS & NS & $0.36^{-}$ & NS & NS & -0.16 & NS & 41 \\
\hline & & & -1.1 & NS & NS & NS & NS & 0.50 & NS & NS & NS & NS & -0.39 & NS & 0.56 & 1.0 & NS & NS \\
\hline \multirow[t]{4}{*}{ Female } & \multirow{4}{*}{\multicolumn{2}{|c|}{$\begin{array}{l}\left(\mathrm{M}_{\mathrm{ij}}\right) \text { WPR } \\
\left(\mathrm{L}_{\mathrm{ij}}\right) \text { WPR } \\
\\
\text { SCWL }\end{array}$}} & NS & NS & NS & NS & NS & NS & NS & NS & NS & NS & -0.54 & NS & 1.5 & 0.81 & NS & -0.61 \\
\hline & & & $0.59^{+}$ & NS & NS & NS & NS & NS & NS & NS & NS & NS & $0.47^{+}$ & -0.51 & -1.9 & -1.4 & -0.36 & 0.47 \\
\hline & & & -0.42 & NS & NS & NS & NS & NS & NS & NS & NS & NS & -0.44 & NS & 1.4 & 0.58 & 0.82 & -0.85 \\
\hline & & & \multicolumn{16}{|c|}{$\mathrm{SE}^{\prime}\left(\mathrm{M}_{\mathrm{ij}}\right)=0.08-0.38 \mathrm{SE}^{\prime}\left(\mathrm{L}_{\mathrm{ij}}\right)=0.10-0.35$} \\
\hline
\end{tabular}

${ }^{+}$- significant line $\mathrm{x}$ diet interaction $(\mathrm{P}<0.05) ;{ }^{1}-$ standard error of mean

NS - non significant 
male progeny were higher for WPR at 18 than $20 \%$ CP diets by 148 and $104 \%$, respectively, and for SCWL at 20 than $18 \%$ CP diet by 248 and $46 \%$, respectively.

\section{CONCLUSIONS}

This study indicates that SCWL males and WPR females exhibited higher combining ability at 18 than $20 \% \mathrm{CP}$ diets. The significant heterosis for BWG and FCR due to sex chromosomes and maternal effects suggests that these two traits are also affected by genes on the sex chromosome for the crosses included in this study.

\section{REFERENCES}

Barbato G.F., Vasilatos-Younken R., 1991. Sex-linked and maternal effects on body weight in young chickens. Poultry Sci. 70, 706-718

Barlow R., 1981. Experimental evidence for interaction between heterosis and environment in animals. Anim. Breed. Abstr. 46, 716-747

Byerly T.C., Kessler J.W., Gous R.M.,Thomas O.P., 1980. Feed requirement for egg production. Poultry Sci. 56, 2500-2507

Carbonell E.A., Nyquist W.E., Bell A.E., 1984. Sex-linked and maternal effects in the EberhatGardner general genetics model. Biometrics 36, 607-616

Chambers J.R., Demon D.E., Gavora J.S., 1984. Synthesis and parameters of new populations of meat-type chickens. Theor. Appl. Genet. 66, 23-30

Eisen E.J., Horstgen-Schwark G., Saxton A.M., Bandy T.R., 1984. Genetic interpretation and analysis of diallel crosses with animals. Theor. Appl. Genet. 65, 17-23

Emsley A., Dickerson G.E., Gowe R.S., 1980. Inbreeding effects on layer performance at two levels of protein intake. Poultry Sci. 56, 1155-1166

Fairfull R. W., 1990. Heterosis. In: R.D. Crawford (Editor). Poultry Breeding and Genetics. Elsevier, Amsterdam (The Netherlands), pp. 613-633

Hruby M., Hamre M.L., Coon C.N., 1995. Free-caloric feeding and three temperature treatments. J. Appl. Poultry Res. 4, 356-365

Hull P., Gowe R.S., Slen S.B., Crawford R.D., 1963. A comparison of the interaction, with two types of environment, of pure strain or strain crosses of poultry. Genet. Res. 4, 370-381

Karen-Zvi S., Nir I., Nitsan Z., Cahaner A., 1990. Effect of dietary energy concentration of fat and energy of fat deposition in broilers divergently selected for high or low abdominal adiposse tissue. Brit. Poultry Sci. 31, 507-516

Leenstra F.R., Vereijken P.F.G., Pit R., 1986. Fat deposition in a broiler sire strain. 1. Phenotypic and genetic variation in, and correlation between, abdominal fat, body weight and feed conversion. Poultry Sci. 65, 1225-1235

Leeson S., Summers J.D., 1989. Response of Leghorn pullets to protein and energy in the diet when reared in regular or hot-cycling environments. Poultry Sci. 68, 546-557

Leeson S., Summers J.D., Caston L., 1993. Growth response of immature brown-cgg strain pullets to varying nutrient density and lysine. Poultry Sci. 72, 1349-1358

National Research Council, 1994. Nutrient Requirements of Poultry. 6th Revised Edition. National Academy Press, Washington, DC 
Noble D.O., Pincard M.L., Dunnington E.A., Uzu G., Larsen A.S., Siegel P.B., 1993. Food intake adjustments of chicks: Short term restriction of genetic stocks to deficiencies in lysine, methionine, or tryptophan. Brit. Poultry Sci. 34, 725-735

North M.O., Bell D.D., 1990. Commercial Chicken Production Manual. 4th Editions. AVI Publishing Co. Van Nostrand, Reinhold, New York, NY

Pesternak H.L, Slalev G., 1983. Effect of nutrient density on growing chicks. Poultry Sci. 62,260

Pesti G. M., 1982. Characterization of the response of male broiler chickens to diets of various protein and energy contents. Brit. Poultry Sci. 23, 527-537

Pincard M.L., Uzu G., Dunnington E.A., Siegel P.B., 1993. Food intake adjustment of chicks: Shortterm reactions to deficiencies in lysine, methionine, and tryptophan. Brit. Poultry Sci. 34, 737-746

Pym R.A.E., 1990. Nutritional Genetics. In: R.D. Crawford (Editor). Poultry Breeding and Genetics. Elsevier, Amsterdam-Oxford-New York-Tokyo, pp. 847-876

Sabri H.M., Wilson H.R., Wilcox C.J., 1991. Comparison of encrgy utilization efficiency among six lines of White Leghorns. Poultry Sci. 70, 229-233

SAS Institute, 1990. SAS/STAT ${ }^{*}$ User's Guide. Version 6. 4th Edition. SAS Institute Inc., Cary, NC

Schulman N., Tuiskula-Haavisto M., Sutonen L., Mantysaari E.A., 1994. Genetic variation of residual feed consumption in a selected Finnish egg-layer population. Poultry Sci. 73, 1476-1484

Sengar S.S., 1987. Feed intake and growth rate pattern in White Leghorn chicks maintained on different planes of nutrition. Poultry Adviser 20, 23-27

Siegel P.B., Picard M., Nir I., Dunnington E.A., Willemsen M.H.A., Williams P.E.V., 1997. Response to meat-type chickens to choice feeding of diets differing in protein and energy from hatch to market weight. Poultry Sci. 76, 1183-1162

Skinner J.T., Waldroup A.L., Waldroup P.W., 1992. Effect of protein and amino acid levels fed zero to fourty-two days on response of broiler to protein and amino acid levels fed fourty-two to fourty-nine days of age. Poultry Sci. 71, 1364-1373

Verma S.K., Chaudhary R.P., 1980. Note on the influence of two-, three- and four-way crosses on growth for broiler production. Indian J. Anim. Sci. 50, 213-214

\section{STRESZCZENIE}

\section{Heterozja przyrostów i wykorzystania paszy u mieszańców White Plymouth Rock i Single Comb White Leghorn odchowywanych na diet:ich o zróżnocowanym poziomie białka}

Porównano heterozję, spowodowaną clumbsimem plciowym, oraz efekty matczyne i linii u mieszańców odwrotnych wzajemnych White Plymouth Rock (WPR) i Single Comb White Leghorn (SCWL). Ptaki od wylęgu do wieku 8 tyg. żywiono dietami zawierającymi 18 lub 20\% białka ogólnego (CP). Ptaki WPR miały większe przyrosty i zjadały więcej paszy niż SCWL, a ptaki WPR żywione dietą zawierającą $20 \% \mathrm{CP}$ były większe niż na diecie $18 \% \mathrm{CP}$. Mimo, że FCR u ptaków SCWL na diecie $18 \%$ CP było niższe niż na diecie $20 \%$ CP w 1 i $3-6$ tygodniach, było ono wyższe niż u ptaków WPR. Hetcrozja był większa u ptaków na diecie $18 \% \mathrm{CP}$, a średni wpływ matczyny i wpływ linii na BWG byly większe $(\mathrm{P}<0,05)$ u WPR niż SCWL i na diecie 18 niż $20 \% \mathrm{CP}$. Efekt matczyny na FCR u potomstwa WPR był jednak większy na diecie 20 niż 18\% CP. Średni wpływ linii był również większy u samców WPR niż SCWL i istotny u obu linii żywionych dietą $20 \% \mathrm{CP}$.

Heterozja spowodowana chromosonem płciowym była istotna $(\mathrm{P}<0,05)$ i dodatnia w przypadku BWG, a ujemna dla FCR. Przeprowadzone badania świadczą o tym, żc samce SCWL i samice WPR wykazują większą zdolność kombinacyjną na diecie 18 niż $20 \%$ CP. Istotna heterozja BWG i FCR spowodowana chromosonem płciowym oraz efekty matczyne pozwalają sądzić, że na obie te cechy mają wpływ geny na chromosomic płciowym. 